\title{
Obstacles Facing Teachers in Palestine While Implementing E-learning During the COVID-19 Pandemic
}

\author{
Ruba Hassan Abu Subaih ${ }^{1}$, Suheir Sulieman $\operatorname{Sabbah}^{2}$ \& Ruqiah Naji Esmail Al-Duais ${ }^{1}$ \\ ${ }^{1}$ Department of Education, Al-Madinah International University, Kuala Lumpur, Malaysia \\ ${ }^{2}$ Department of Psychology, Al-Quds University, Jerusalem, Palestine \\ Correspondence: Suheir Sulieman Sabbah, Department Psychology, Al-Quds University, Jerusalem, Palestine. \\ E-mail: ssabbah@staff.alquds.edu
}

Received: January 15,2021

Accepted: March 6, 2021

Online Published: March 31, 2021

doi:10.5539/ass.v17n4p44

URL: https://doi.org/10.5539/ass.v17n4p44

\begin{abstract}
The study aims to identify the obstacles facing teachers in Palestine society while adopting e-learning during the COVID-19 pandemic. The results show the most critical obstacle continues to be the infrastructure of the educational system. Other obstacles include technical support, the readiness of all stakeholders, and remote technological education skills and competencies. The study also shows many obstacles, including students' failure to attend classes in full, assessment of students, and learning online. The study highlights the critical success factors for the adoption of e-learning. E-learning requires skills and competencies for both teachers and students. Teachers must also adopt various teaching methods accounting for individual differences, learning styles, and psychological support. Those teaching methods need advanced training before implementing them in Palestine. Additional recommendations were made including spreading electronic culture, increasing awareness of society partnership, enriching teacher education programs, conducting trainings for teachers, and conducting further researches similar to this study.
\end{abstract}

Keywords: obstacles, Palestinian teacher, E-learning, Covid-19 pandemic, 21st Century Skills

\section{Introduction}

The outbreak of COVID-19, also known as the Coronavirus, has been affecting lives around the world for over a year. It has been actively disrupting the educational process for almost 300 million students around the world (UNESCO, 2020). Schools and universities have closed; parents are supporting their children with the learning process via home schooling. Arab countries, including Palestine, were not immune from this crisis.

Palestine declared a state of emergency in March 2020, disrupting the educational process. The Palestinian educational system, with its limited capabilities, was not prepared to use e-learning in its defined sense. As a result, discussions have risen about alternative plans on ways to continue the academic service and the spring 2020 school semester. Many initiatives to maintain contact between teachers and their students were introduced, including the use of social media. Communication between teachers and their students took place using Google Meet, Zoom, Facebook Groups, WhatsApp, and other means.

E-learning has become a topic of discussion in Palestine among the educational community; it has moved from an alternative educational method to the traditional way without planning (Al-Khair \& Ghoneim, 2019). According to (Hinnawi \& Najm, 2019; Almehmadi, 2018) the current situation created uneasiness for teachers, students, and parents due to the following reasons:

1. Ability to use the e-learning as an educational system,

2. Lack of a clear and systematic academic plan,

3. Lack of infrastructure and equipment,

4. Lack of comprehensive electronic curriculum,

5. Lack of preparation for both teachers and students.

However, the challenges and obstacles imposed by the Coronavirus could be transformed into the perfect opportunity for advancing the problem solving skills and digital capabilities in this century (Onyema et al., 2020; 
Sintema, 2020). Developing these skills is important for decision-makers in education to confront the challenges and obstacles of e-learning facing teachers. Additionally, diagnosing the challenges would help teachers and decision-makers in public and private schools face these obstacles and address them for a successful implementation of the e-learning system or adopt it as an educational system in normal conditions as well (Onyema et al., 2019).

The problem statement is based on the experience of researchers in education through their observation of the reality of the education system in Palestine, especially during the COVID-19 pandemic period. They observed the confusion that occurred with teachers, students and parents in figuring out how to deal with such a crisis, since most teachers adhere to traditional teaching methods. Moreover, the researchers have reverted to previous studies and literature review, and found that the study of the difficulties that teachers face in e-learning in Palestine in light of the COVID-19 pandemic has not been given attention or investigated. Rather, the few studies available that were accessed covered a period prior to the outbreak of the pandemic and were limited in their scope (Shaqour, 2013; Zamel, 2009; Hadijah \& Shalawati, 2017). From this standpoint, this study aims to identify the obstacles facing teachers when using e-learning in Palestine in light of the COVID-19 pandemic, and to identify the needed skills, competencies, and the proposed training that helps them with e-learning in light of COVID-19.

This study tried to answer the following questions:

1. What are the obstacles that teachers face when using e-learning in Palestine in light of the COVID-19 pandemic?

2. What are the needed competencies and skills that teachers should have to overcome these obstacles?

\subsection{Literature Review}

E-learning is an education system based on the use of computers and the Internet to deliver educational content to learners (Al Qadah \& Muqablah, 2013). It refers to an integration of pedagogy, content, and technologies within a teaching and learning context (Sangrà et al., 2012). It can include face-to-face classrooms in which information technologies such as video-conferencing are used. E-learning is also an experience that can occur synchronously, asynchronously, or as a combination of the two (Cantoni, 2004).

Despite different attempts by the Palestinian Authority to develop the e-learning infrastructure, teachers continued to rely on traditional methods that do not develop creative thinking (Abu Al-Khair, 2019). Therefore, the inability to provide the means of e-learning technology is an obstacle facing e-learning advancement in the Palestinian educational institutions (Sharaf, 2006; Shaqour, 2013). In addition, learner's lack of technical and research experience is another obstacle. The same can also be said about the teachers and educators (Al-Mallah, 2010, p. 80).

E-learning is an innovative way to provide an interactive learner-centered environment (Ellis \& Goodyear, 2010). It has to be well designed and accessible to information sources while obtaining and processing information (Herrington, Reeves, \& Oliver, 2010, p. 45). The role of the teacher consists of supervising, guiding, and facilitating the educational process (Al- Mallah, 2010). The teacher helps students to remain motivated to learn and use technology in aknowledge-based era (Ismail, 2009).

In order for e-learning to achieve its goals, the following conditions must be met from the teacher/educator: (a) Teacher must have the ability to teach and use modern teaching techniques (Al- Hassan, 2010); (b) Teacher must encourage the students and generate knowledge and creativity (Kotaite, 2009); (c) Teacher should adopt the role of facilitator, evaluator, leader and driver of classroom discussions (Abdulaziz, 2008). The following conditions must also be met from the learner: The learner should have the skills of self-learning, communication skills, critical thinking, teamwork and the ability to use computers, (Amer, 2007; Jad \& Asim, 2015). Finally, the following conditions must be met from the infrastructure: there should be the existence of technical support, and the central administrative staff (Mahamdeh, 2005). There should also be enough basic equipment that includes service devices with the availability of the Internet.

In spite of the importance and benefits of e-learning, obstacles do exist, such as the lack of standards, especially for educational curricula, and the lack of clarity of regulations and compensatory incentives that motivate and encourage students to e-learning (Tarus, Gichoya, \& Muumbo, 2015). Other obstacles include weak infrastructure (Kisanga \& Ireson, 2015). According to (Varshneya, 2018), e-learning in developing countries is still in the initial stages and faces many challenges, such as the high cost of acquiring, installing, and operating information and communication technology. Other obstacles include the lack of qualified trained teachers and educators to use the Internet efficiently (Al-Mallah, 2010), and the lack of customized content which creates a 
feeling of dissatisfaction among students and teachers (Amer, 2007: 74), and the lack of accredited educational electronic models in the Arabic language (Shailendra Palvia, elt, 2018).

Other obstacles facing teachers include the rearrangement of exams and allowing open book. The issue of assessment and grades is a real problem when students stay out of school/classroom. The quality of online learning needs future study (Basilaia, \& Kvavadze, 2020). The literature review shows that the teacher's role in the educational process is crucial even with the latest technologies (Hinnawi and Najm, 2019). If teachers do not understand the meaning and impact of e-learning on education, they are likely to resist or avoid its use, which leads to an institutional failure in the adoption of e-learning methods and technology, thereby limiting its use and generalization.

\section{Method}

The current study used descriptive and analytical approaches for their appropriateness for this kind of research. A qualitative research approach was employed to find the most pressing issues viewed by teachers. These issues consisted of barriers and obstacles when implementing e-learning during the COVID- 19 pandemic.

\subsection{Study Sample}

To know the most important barriers and obstacles facing teachers when implementing e-learning during the COVID-19 pandemic, the researchers chose a sample of school teachers in Palestine. Those teachers had different specializations and taught different subjects. Their teaching experiences ranged between one to ten years, from private and governmental schools. The Distribution of the Demographic Information of the participants was as follows:

Table 1. Distribution of the Demographic Information of the Participants

\begin{tabular}{ccc}
\hline Variable & Number & Percentage \\
\hline Gender & 10 & \\
Male & 46 & 21.10 \\
Female & & 82.1 \\
Specialization & 17 & 30.40 \\
Science & 39 & 69.9 \\
Humanities and Literary & & \\
Experience & 7 & 12.5 \\
Less than 5 years & 15 & 26.8 \\
5-10 years & 34 & 60.7 \\
More than 10 years & & \\
Type of School & 18 & 32.1 \\
Private & 38 & 67.9 \\
Government &
\end{tabular}

\subsection{Data Collection}

Open-ended questions captured the obstacles in implementing e-learning. The questions were in Arabic and were sent to teachers through emails and via social media using the snowball technique. The questions gave freedom to the researchers to probe more deeply and to extend the responses of the study participants, (Braun \& Clarke, 2012). The open-ended questions were conducted to deeply explore the participating teachers' views and perceptions about the distance-learning integration in Palestinian schools. The participants were assured of the confidentiality of their responses and informed that they would only be used for research purposes. The teachers were asked to express their views, concerns and perceptions freely and honestly regarding the distance-learning integration. Participating teachers' permission was taken to respond to a set of questions.

\subsection{Data Analysis}

The form and content of the questions were validated by experts' opinions: all reviewers approved its validity and suitability for the purposes of the study. As applied in other qualitative studies, transcripts were coded in a systemic manner using open-coding procedures (Miles \& Huberman, 1994). Responses were examined thoroughly and deeply. A deep analysis of such responses enabled the researchers to identify the general patterns or themes of the participating teachers' views, concerns and perceptions regarding the implementation of e-learning. There were similar patterns of thoughts expressed in the teachers' answers that had direct relevance to 
the purpose of the study. After the consideration of the thematic issues, it was possible to group the questions into five main categories, which became the basis for the interpretation of issues perceived by teachers. Frequencies and percentages of answers are provided in Appendix A.

\section{Results}

This exploratory study reports the perceived views of a sample of teachers in Palestine. The deep analysis of the data revealed that the obstacles of e-learning in Palestine areas follow:

\subsection{Infrastructure}

Obstacles related to Infrastructure and Technical Support at a rate of $(80 \%)$. The obstacles in infrastructure consisted of Poor Internet services, high cost, and a lack of computers and laptops devices for both teachers and students, since many have only one device for the entire family. Respondents were quoted with the following issues:

1. The lack of adequate devices in all homes;

2. Poor Internet services for students;

3. Lack of knowledge of remote communication programs;

4. Difficulty of communication due to poor networks;

5. Difficulty is displaying media that help students understand concepts;

6. Lack of follow-up from Administration.

\subsection{Distance Education}

Obstacles related to experience in the field of technological distance, education skills and readiness for using e-learning in teaching (curriculum and its design, educational methods, teaching methods and evaluation methods). $78.5 \%$ of teachers' responses focused on weak technology-use skills in e-learning as well as difficulty of customizing the traditional curriculum to be used for online training material such as presentations, activities, and exercises that enable the student to do assignments inside the home. They also focused on the lack of training in teaching skills remotely and the lack of a clear agreed mechanism for remote assessment and evaluation, in addition to the absence of electronic educational links and educational programs to support the online curriculum. Moreover, according to the responses, there are no special communication programs to ease communication among teachers and students remotely and professionally.

Examples of answers from respondents: "Difficulty searching for educational links and trying to find an appropriate method to convey the information to students, trying to make a personal video"; "Not giving the material in the way it's supposed to be taught"; "The institutions and teachers are not prepared to use technology"; and "The problem was that we were not prepared for such new programs that we were not being exposed to before". Also, "the limited equipment at home did not help in learning and searching for these programs quickly"; "a lack of technology skills for education," "Failure to build the traditional curricula in a way that helps to adapt it to an online one when necessary," "the absence of guide within the curriculum that explains how to use the Internet in education," "Difficulty using technology in education, lack of quality photography and lack of capabilities," "Lack of educational resources and strategies suitable for remote use." Furthermore, another respondent said: "Zoom application is not easy to explain, and solve mathematics problems, so I had to record lessons in the form of video and send them to students."

\subsection{Communication and Attendance}

Obstacles related to students: (76.7\%) of teachers had difficulties communicating with students. Students are not fully committed to attending virtual classes and doing their assignments in addition to the lack of motivation and interest. Another obstacle was the large number of students per class: class sizes can range anywhere between 25-50 students. Teachers also mentioned that there was great difficulty in dealing with students who have disabilities and/or low achievement students. The following responses are the most frequent examples of teacher's answers: "Lack of daily communication with students, in addition to the lack of discipline in the number of students who follow-up," "The students' failure to respond to distance education, perhaps for several reasons, including their lack of qualification for that kind of learning, or their lack of motivation because they are accustomed to empirical education, which depends on their direct communication with the teacher." Other sample responses were: "Students' failure to respond to distance learning and their disdain for it," "lack of interactive spirit affects the learning process negatively, lack of commitment from the students and the difficulty of following up accurately," "poor commitment to the lessons," "lack of motivation, lack of attention," and 
"difficulty gathering students at the same time." Other comments included, "difficulty in conveying the information due to individual differences," "Inability to reach all students with disabilities or those with low achievement levels," "the large number of students in the class," and "the lack of Internet service for some students at home."

\subsection{Commitment from Parent}

Obstacles related to Parents: (53\%) of responses related to the parents' lack of knowledge of remote e-learning programs and the mechanism of their use. That and the different cultural and educational levels of parents led to difficulty in helping children with the technology and following up with them, which in turn led to receiving complaints from parents about the e-learning process/technology.

Lack of interest in distance learning is also clear in the answers. In addition there is the issue of parents' preoccupation with other obligations related to the family, as you will commonly find parents playing a secondary, non-essential role in their child's education, and leaving the main burden to the school and teachers. Examples of respondents: "Difficulty in commitment from parents' side and doing tasks with students," "Some parents failed to communicate and did not respond to tasks, home works and duties of distance learning," "Parents' constant complaints that students are not satisfied with studying online, and some students do not interact in solving assignments," and "Difficulty communicating effectively with parents and performing various tasks."

\subsection{Inexperienced Teachers}

Obstacles related to the teacher, with a rate of $(44.6 \%)$ in response. Many teachers expressed that they lack experience with using e-learning technology/methods. Additionally, the COVID-19 pandemic situation and the imposed quarantine have created a general state of lack of adaptation, psychological pressures, a sense of fear, and the presence of resistance to learning new skills in education.

Some answer quotes are as follows: "Discontinuation from traditional education (face to face), students, and teaching the subject directly," "Fear of spreading the Pandemic and closure of roads and transportation," "Lack of adaptation to the new situation," "Lack of knowledge," "I did not receive in-service training on how to use the internet and technology in teaching," "My poor level in the English language in searching for educational sites in the English language," and "I am not convinced of the importance of electronic education."

The teachers were also asked to circle the biggest problems facing them during COVID-19 when it comes to using electronic education, within a list of problems. The results appeared as follows in descending order: (Appendix B). It appears that the teachers' most pressing concern is the students' lack of commitment to attend the full classes at a rate of $91 \%$. And among the problems there is also no clear tool for evaluation by $82 \%$ as teachers are not equipped to work in an emergency situation. The Internet is weak, or interrupted continuously by $80 \%$; and the lack of interaction with the teacher by $78.5 \%$, which shows the students' lack of commitment to distance learning and self-reliance. Students are dependent on traditional, face-to-face education more than self-reliance. In addition, there is the absence of technical support from the school by $60 \%$, although some schools lack a specialized IT department altogether; this showed that there are also problems in operating the educational system, if any, at a rate of 59\%. As an inevitable result, the difficulty of learning appears on e-learning programs and the limited educational programs in the Arabic language by $50 \%$.

The results also showed that most of the teachers were facilitating and directing their role in education as much as possible $(51.9 \%$, \#29), while others had a traditional role $(17.8 \%, \# 10)$, and $(25 \%$, \#14) used both. Three of the teachers had no contact with the students at all. To clarify further, teachers were asked a question about a problem that they encountered while doing distance education; (89\%, \#50) of respondents said that they had indeed faced a problem, most importantly:

1. Lack of knowledge of effective programs to communicate with students and administration.

2. The difficulty in communicating information properly and clearly with the low achievement students, and not taking individual differences into account.

3. Difficulty using computers and limited educational programs in the Arabic language.

4. The limited availability of electronic educational programs for the stage curricula, noting that the language of instruction and curricula is in Arabic in Palestine.

The second question: What skills and competencies do you think are important and needed in using the e-learning in light of COVID- 19? What are the suggested trainings to help you in using e-learning?

Regarding the skills that the teachers believe are important in e-learning in light of the COVID-19 pandemic crisis, they have been divided into the following groups: Cognitive Skills, Social and Performance Skills, and 
Adaptive and Self-Management skills:

\section{A. Cognitive Skills}

a) Creativity and Innovation (96\%) is the ability to use the available resources in an unfamiliar way to reach all that is new and break from stereotypes.

b) Problem Solving (92.8\%) is the ability to gather facts and relate information to reach multiple solutions.

c) Critical Thinking (66\%) is the ability to logically analyze, think independently, evaluate information and verify.

B. Social and Performance Skills

a) Technological Skills (94.6\%) is the ability to use social media platforms in education and e-learning programs.

b) Communication and Teamwork $(87.5 \%)$ is the ability to communicate with others and work in a team.

c) Social Skills and Emotional Intelligence $(82.1 \%)$ is the ability to understand oneself, understand others, empathize with them, and understand their feelings.

C. Adaptive and Self-Skills

a) Flexibility and Adaptability (94.6\%) is the ability to learn new concepts and adapt to different situations.

b) Leadership and Responsibility (91\%) is the ability to influence others and take the initiative to solve problems.

c) Initiative and Self-Direction (87.1\%) taking the initiative when faced with a problem and being able to self-evaluate and choose special learning topics.

The most important skills and competencies that ateacher will need in e-learning in light of COVID- 19:

1. Knowledge of technological programs, such as: illustration animations, making educational videos, and uploading video clips;

2. Communication and remote communication with students, colleagues, and parents;

3. Art of teaching (the art of e-learning), work papers and electronic exams;

4. Being able to search from educational electronic websites (surfing skills);

5. Creating new solutions, and developing higher thinking skills (creative and analytical thinking);

6. Thinking, innovation and entrepreneurship skills; social, adaptive, performance, and emotional intelligence skills;

7. People management and self-management skills.

As for the suggested training to help teachers with e-learning:

1. Technological skills and training in the art of photography;

2. Courses for students and parents on distance learning;

3. The using of social networking sites such as Facebook, Twitter, or others;

4. Searching through search engines and advanced searchon the Internet;

5. Training on e-learning programs, Zoom, K12K, Google Drive, Bix meet;

6. Leadership and crisis management training;

7. How to handle the curriculum remotely;

8. Using advanced teaching methods that take into account the individual differences between students and those with learning difficulties;

9. Psychological support training.

\section{Discussion}

The answers to the open-ended questions by the in-service teachers showed that the most important obstacles to e-learning technology integration in Palestinian schools as perceived by them, in light of the COVID-19 
pandemic, are, respectively, (1) obstacles related to infrastructure and technical support, followed by (2) obstacles related to experience in the field of distance technology education skills, and the readiness for education (curriculum and its design at a distance and educational methods of teaching), followed by (3) obstacles related to the student, (4) to parents and finally, (5) obstacles related to the teachers themselves.

Regarding obstacles faced by teachers in the implementation of e-learning as an education system, the study showed that $90 \%$ of teachers faced obstacles, most importantly: (1) students' failure to attend classes in full, followed by (2) the inability to evaluate students in more than one way, then (3) the weakness of the Internet, or its continuous interruption, (4) the absence of technical support from the school, and problems in the operation of the system, and finally, (5) the difficulty of learning on e-learning programs. The above results match with (Al-Jarbawi, 2020) conclusions in light of the COVID-19 pandemic that "there is a shortage of infrastructure and equipment. For example, there are many areas in Palestine where electricity is cut off for long periods, and the quality and extent of the Internet is still deficient, in addition to the economic situation of many families that does not allow them to buy devices and computers for the students, the possibility of providing a favorable environment at home is limited or absent for many parents." Additional obstacles include the lack of comprehensive electronic curricula that are subject to quality standards, as well as the need for an approach for evaluating methods in e-learning that is completely different from the examination-based assessment methods in use in education today. Moreover, the process of preparing exams, preparing teachers and students should also be different; deficiencies in all aspects of the process, whether in curriculum and content, evaluation, or their ability to use technical skills are available (Al-Mallah, 2010) (Kotaite, 2009) (Al-Khan, 2005). "There is a lack of a clear and systematic mechanism or plan," (Basilaia \& Kvavadze, 2020). This agreed with (Sharaf, 2006) conclusion about the inability to provide computer equipment and their requirements, effective software, facilitate Internet connection, and provide permanent maintenance and research centers and other information. It also agreed with (Al-Mousa, 2003) about the lack of clarity of compensatory regulations and incentives that motivate and encourage students to e-learning, which creates a sense of dissatisfaction among students and teachers (Al- Hawamda, 2011) and (El-Hersh, Muflih and Aldhoon, 2010). That also agreed with (Sahu, 2020) (Sintema, 2020) (Shailendra Palvia, elt, 2018), who indicated that electronic education for students, especially in the early stages of the COVID-19 pandemic, is one of the greatest difficulties facing the teachers, considering that e-education focused on higher education students leaving out thousands of primary and secondary school students.

As per the e-learning obstacles related to the teacher, some teachers have a fear of developing or implementing e-learning for the following reasons: (1) their unwillingness to change and interest in adherence to the traditional pattern, or (2) the pre- misconception that e-learning may cancel the role of the teacher as explained by (Hennesy, 2010), in addition to (3) absence of financial incentives, as well as (4) the psychological aspect and the problem of their acceptance of the electronic form of information sources that push teachers to prefer the traditional method of teaching (Amer, 2007: 74). In addition to the lack of financial resources and facilities and obstacles to the educational and administrative system (Khamis, 2003: 256), there was a lack of the teachers' participation in preparing and building the educational material (Al-Kandari, 2011), lack of adequate training for the use of technology (Zamil, 2009), and insufficient availability of devices for them (Shaqour, 2013).

It is noteworthy that the answer(s) to the second question of the sample expressed the teachers' needs for the skills and competencies, the most important of which are: (1) knowledge of technological programs, (2) remote communication with students and colleagues, and parents, (3) the skill of the art of teaching (the art of e-learning), (4) the development of higher thinking, innovation, entrepreneurship, and social skills, as well as (6) adaptive, performance, and emotional intelligence. Therefore, they need the training that they proposed to help them in e-learning, the most important of which are: (1) training in technological skills, (2) training in the art of photography, (3) conducting training courses for students and parents for distance learning, and (4) searching through search engines and advanced research on the Internet. Additional programs includes leadership training, crisis management, how to deal with the curriculum remotely, and training in advanced teaching methods that take into account individual differences between students, especially those with learning difficulties and psychological support. In other words, they need training in the skills of the 21 st century, or what is also known as the skills of the era of knowledge economy, in order to keep pace with the rapid changes and the accumulated explosion of knowledge, as well as to deal with digital generations and manage crises in a practical and effective manner.

\subsection{Conclusion and Recommendation}

In light of the COVID-19 pandemic and the consequent reflection of using different educational methods in Palestine including e-learning, this study investigated the obstacles hindering the implementation of e-learning 
in Palestinian Schools. In this study, it emerged that implementation of e-learning in Palestine faces a number of obstacles which include but are not limited to the lack of e-learning infrastructure and technical support, difficulties related to lack of teacher experience in distance education skills, readiness for education, difficulties related to students and parents, and finally, difficulties related to the teacher. The study also showed the most important obstacles facing the teacher: the lack of commitment of students to attend the full lessons, followed by the limited number of ways for evaluating students. Additional obstacles include the weakness of the Internet or its continuous interruption, the absence of technical support from the school, problems in the operation of the educational system, and finally, the difficulty of learning on e-learning programs.

This study also concludes that the most important skills and competencies teachers should have to deal with the rapid changes in the technological era include the 21 st century skills such as the skill of creativity and innovation, the skill of using technology and flexibility, the ability to adapt, communication, collaboration, and the art of teaching.

The abovementioned competencies would be achieved by implementing customized training in (1) technological skills, (2) in conducting training courses for students and parents about distance learning, (3) training in leadership and crisis management (4) dealing with the curriculum remotely, (5) and training on advanced teaching methods that take into account individual differences between students, especially those with learning difficulties.

In reference to the abovementioned obstacles, this study has suggested various recommendations:

1. Work on spreading electronic culture among members of society to achieve the greatest amount of interaction with this type of education;

2. Enhance the interest in infrastructure and its technical and technological equipment in order to create appropriate conditions for teachers to use the distance learning system in teaching;

3. Increase the awareness of society partnership to make education available for all.

4. Conduct training for teachers to develop the skills of the 21 st century that would help in dealing with crises and with the requirements of the knowledge economy era;

5. Enrich the teacher's preparation program with the skills of the 21 st century skills to ensure preparing the teachers before they go into the field; and

6. Conduct more studies similar to this study to include wider educational areas and a larger sample to be able to generalize the results of this study.

\subsection{Limitations of the Study}

This study is limited to teachers in public and private schools in Ramallah region in Palestine, where they were reached through various social media by presenting open questions via an online form during quarantine in the period between March 15, 2020 and May 5, 2020. Conducting in-person interviews was not possible due to the pandemic shutdown.

\section{Acknowledgments}

The authors would like to thank Dr. Malik Saleh. Dean, College of Business Administration, Prince Mohammad Bin Fahd University, Al Khobar, Saudi Arabia, for translation checking, proofreading and helpful feedback on this paper.

\section{References}

Abdul-Aziz \& Hamdy. (2008). E-Learning Philosophy - Principles - Tools - Applications - Dar Al Fikr, The Hashemite Kingdom of Jordan, Amman (1st ed.).

Abu al-Khair, A. G. (2019). The obstacles facing the school administration in implementing e learning from the point of view of principals and teachers in primary schools in Gaza governorate. The Journal of Palestine Technical Univ. for Research, 7(3), 1-15. Retrieved from https://scholar.ptuk.edu.ps/handle/123456789/749

Al Malah, M. (2010). The electronic school and the role of the Internet in education. Amman: House of Culture for Publishing and Distribution.

Al-Hassan, E. I. K. (2010). E-learning: a step to meet the growing demand for Arab university education and reduce the digital gap in it. Journal of the College of Education: University of Khartoum - College of Education, 3(4), 111-144.

Al-Hawamdeh, M. F. (2011). Obstacles to using e-learning from the point of view of faculty members at Al-Balqa Applied University. Damascus University Journal, 27(1+2), 803-831. Retrieved from 
http://search.shamaa.org/FullRecord?ID=30875

Al-Kandari, W. et al. (2011). Obstacles to the Application of E-Learning in the State of Kuwait: An Educational and Social Study. Abhath Al Yarmouk: Humanities and Social Sciences, 27(3).

Al-Khan, B. (2005). E-Learning Strategies. Translated by Ali Al- Mousa and others, Shuaa for Publishing and Distribution, Syria.

Almehmadi, G. A. (2018). Evaluating the reality of using e-learning management system (EMES) in KAAU from the students. Basic Education College Magazine For Educational and Humanities Sciences, 39, 177-196. https://www.iasj.net/iasj/article/145218

Al-Mousa, A. (2003). E-learning: its concept - its characteristics - its benefits - its obstacles. A working paper presented to the Future School symposium in the period 16-17/8/1423 University King Saud.

Al-Qudah, K., \& Youssef, B. M. (2013). E-learning challenges facing faculty members in private Jordanian universities (Published Master's Thesis). Al-Manara Magazine.

Amer, T. (2007). Education and electronic school. Egypt: Dar Al-Sahab.

Basilaia, G., \& Kvavadze, D. (2020). Transition to Online Education in Schools during a SARS-CoV-2 Coronavirus (COVID-19) Pandemic in Georgia. Pedagogical Research, 5(4), em0060. https://doi.org/10.29333/pr/793

Braun, V., \& Clarke, V. (2012).Thematic analysis. APA Handbook of Research Methods in Psychology, 2(Research Designs: Quantitative, Qualitative, Neuropsychological, and Biological)(2), 57-71. https://doi.org/10.1037/13620-004

Cantoni, L. M. (2004). World Conference on Educational Multimedia, Hypermedia \& Telecommunications, AACE, Norfolk. Retrieved from https:/files.eric.ed.gov/fulltext/ED476959.pdf

El-Hersh, A., Muflih, M., \& Aldhoon, M. (2010). Obstacles of the Application of E-Learning Systems as Viewed by Secondary School Teachers at Al-Kurah District. Jordan Journal of Educational Sciences, 6(1), 27-40.

Ellis, R., \& Goodyear, P. (2010). Students' experiences of e-learning in higher education the technology of sustainable innovation. New York, NY: Routledge. https://doi.org/10.1111/j.1467-9647.2010.00678.x

Hadijah, S., \& Shalawati, S. (2017). Investigating Teacher 'Barrier to ICT (Information Communication Technology) Integration in Teaching English at Senior High School in Pekanbaru. Proceedings of ISELT FBS Universitas Negeri Padang, 5, 302-310. Retrieved from http://ejournal.unp.ac.id/index.php/selt/article/viewFile/8019/6121

Hennessy, S., Harrison, D., \& Wamakote, L. (2010). Teacher factors influencing classroom use of ICT in sub-Saharan Africa. Itupale Online Journal of African Studies, 2, 39-54. Retrieved from https://pdfs.semanticscholar.org/56ec/8d2248a546352fed0f520972b57034334a45.pdf

Herrington, J., Reeves, T., \& Oliver, R. (2010). A guide to authentic e-learning. New York, NY: Routledge. https://doi.org/10.4324/9780203864265

Ismail, Al-G. (2009). E-courses, their design, production, publication, implementation, and evaluation (1st ed.). The World of Books, Cairo.

Jad, M. M. M., \& Assem, D. M. (2015). Designing a proposed electronic environment to develop an Open University education system in light of foreign experiences. Studies in university education: Ain Shams University - College of Education, University Education Development Center, pp. 31, 299-410. https://doi.org/deu.2015.19362/10.21608

Jarbawi, T. (2020). Corona Speeds up Plans for Distance Education in Palestine. Retrieved from https://www.alayyam.info/

Khamis, M. (2003). Educational technology products. Cairo, Dar El Kalima.

Kisanga, D., \& Ireson, G. (2015). Barriers and strategies on adoption of e-learning in Tanzanian higher learning institutions: Lessons for adopters. International Journal of Education and Development using Information and Communication Technology 11(2), 126-137. $\quad$ Retrieved from http://ijedict.dec.uwi.edu/viewarticle.php?id=2003

Kotaite, G., \& Khuraisat, S. (2009). Computer, Teaching Methods and Evaluation. House of Culture, Amman.

Mahamdeh, N. (2005). Continuing Education and Self-Education. Safaa Publishing House, Amman. 
Majdi, M. R., \& Hinnawi, R. N. N. H. (2019). E-Learning: Competencies, Attitudes \& Obstacles. Journal of the Arab American University, 5(2).

Miles, M. B., \& Huberman, A. M. (1994). Qualitative Data Analysis: An Expanded Sourcebook. Thousand Oaks, CA: Sage Publications. Retrieved from http://www.jstor.org/stable/24332877

Onyema, E., Nwafor, C., Faith, A., Sen, S., Atonye, F., Sharma, A., \& Alsayed, A. (2020). Impact of Coronavirus Pandemic on Education. Journal of Education and Practice, 11, 108-121. https://doi.org/10.7176/JEP/11-13-12

Onyema, E. M. (2019). Integration of Emerging Technologies in Teaching and Learning Process in Nigeria: The challenges. Central Asian Journal of Methemetical Theory and Computer Science, 1(1), 35-39. Retrieved from https://www.researchgate.net/publication/336278814

Sahu P. (2020). Closure of Universities Due to Coronavirus Disease 2019 (COVID-19): Impact on Education and Mental Health of Students and Academic Staff. Cureus, 12(4), e7541. https://doi.org/10.7759/cureus.7541

Sangrà, A., Vlachopoulos, D., \& Cabrera, N. (2012). Building an inclusive definition of e-learning: An approach to the conceptual framework. International Review of Research in Open and Distance Learning, 13(2), 145-159. https://doi.org/10.19173/irrodl.v13i2.1161

Palvia, S., Aeron, P., Gupta, P., Mahapatra, D., Parida, R., Rosner, R., \& Sindhi, S. (2018). Online Education: Worldwide Status, Challenges, Trends, and Implications. Journal of Global Information Technology Management, 21(4), 233-241. https://doi.org/10.1080/1097198X.2018.1542262

Shaqour, A. (2013). Reality of employment of technological innovations and the constraints of this employment in west bank and Gaza strip schools from the teachers' perspective. An-Najah University Journal for Research (Humanities), 27(2). Retrieved from https://journals.najah.edu/article/901/

Sharaf, F. (2006). Palestinian virtual education prospects and its role in political development (towards a Palestinian virtual university).

Sintema, E. J. (2020). E-Learning and Smart Revision Portal for Zambian Primary and Secondary School Learners: A Digitalized Virtual Classroom in the COVID-19 Era and Beyond. Aquademia, 4(2), ep20017. https://doi.org/10.29333/aquademia/8253

Tarus, J., Gichoya, D., \& Muumbo, A. (2015). Challenges of Implementing E-Learning in Kenya: A Case of Kenyan Public Universities. International Review of Research in Open and Distributed Learning, 16(1), 120-141. https://doi.org/10.19173/irrodl.v16i1.1816

UNESCO. COVID-19 Education Response. Retrieved April 5, 2020, from https://en.unesco.org/covid19/educationresponse/globalcoalition

Varshneya, A. (2018). Distance Learning through ICT: Benefits and Challenges. Journal of Advanced Research in English \& Education, 2(3\&4). Retrieved from https://science.adrpublications.in/index.php/Journal-English-Education/article/view/396

Zamel, M. (2009). The difficulties that face teachers of the tenth grade primary school teachers in using computers as an aid in education in Ramallah and Al-Bireh Governorate. Journal of Al-Quds Open University for Research and Studies - Issue sixteenth. 59-100. Retrieved from https://search.emarefa.net/detail/BIM-76400

\section{Appendix A}

Table 2. Obstacles to E-learning Technology Integration in Palestinian Schools as Perceived by In-service Teachers

\begin{tabular}{lcc}
\hline Obstacles & Frequency & Percentage \\
\hline Obstacles related to infrastructure and technical support & 45 & $80 \%$ \\
Obstacles related to experience in the field of technological distance education skills and & 44 & $78.5 \%$ \\
readiness for education & 43 & $76.7 \%$ \\
Obstacles related to the student & 30 & $53 \%$ \\
Obstacles related to parents & 25 & $44.6 \%$ \\
Obstacles related to the teacher & & 25 \\
\hline
\end{tabular}

* Total number of in-service teachers interviewed is 56. 


\section{Appendix B}

Table 3. The Obstacles Facing the Teachers in E-learning in Light of the COVID-19 Pandemic

\begin{tabular}{lcc}
\hline Obstacles & Number & Ratio \\
\hline Difficulty learning on e-learning programs & 30 & $50 \%$ \\
Problems operating the educational system & 33 & $59 \%$ \\
The absence of technical support from the school & 34 & $60 \%$ \\
Students' lack of interaction with the teacher & 44 & $78.5 \%$ \\
The weakness of the Internet, or its continuous interruption & 45 & $80.3 \%$ \\
The inability to evaluate students in more than one way & 46 & $82 \%$ \\
Non-commitment of students to attend classes in full & 51 & $91 \%$ \\
\hline
\end{tabular}

\section{Copyrights}

Copyright for this article is retained by the author(s), with first publication rights granted to the journal.

This is an open-access article distributed under the terms and conditions of the Creative Commons Attribution license (http://creativecommons.org/licenses/by/4.0/). 